\title{
THE SAFETY OF SHIP DURING BERTHING MANOEUVRE PROCESS TO THE QUAY
}

\section{BEZPIECZEŃSTWO STATKU W PROCESIE MANEWRU CUMOWANIA STATKU DO NABRZEŻA}

\author{
Wieslaw Galor \\ Institute of Marine Traffic Engineering, Maritime University of Szczecin \\ Instytut Inżynierii Ruchu Morskiego, Akademia Morska w Szczecinie \\ 70-500 Szczecin, ul. Wały Chrobrego $1 / 2$ \\ e-mail: galorw@am.szczecin.pl
}

\begin{abstract}
The berthing of ship to the quay is last stage of navigation advance. An ideal manoeuvre would be consisted in a total loss of speed at the moment the ship makes contact with the quay. The accident can happened as results of unwanted ship's strike to the quay. In results, the damage of ship's hull or port structure can occur. It can happened when will be exceeding the admissible energy during contact the ship-quay. The fenders improve the safety of berthing operations by partially absorbing the kinetic energy of ship. The paper presents the analysis of risk of accident when ship berthing. Besides, the possibility of its decreasing by use of fenders will be considered.
\end{abstract}

Keywords: safety of navigation, ships berthing, fenders

Streszczenie. Manewr cumowania statku do nabrzeża jest ostatnim etapem procesu nawigacji. Manewr idealny polega na całkowitym wytraceniu prędkości statku w momencie kontaktu z nabrzeżem. Lecz należy się liczyć z tym, że może zdarzyć się wypadek jako niepożądane uderzenie statku w nabrzeże. Może to wystapić, gdy zostanie przekroczona dopuszczalna energia podczas kontaktu statek- nabrzeże. W rezultacie, może wystąpić uszkodzenie kadłuba statku lub budowli portowej. Urządzenia odbojowe poprawiają bezpieczeństwo cumowania poprzez częściowa absorpcję energii kinetycznej statku. Referat przedstawia analizę ryzyka wypadku podczas cumowania statku. Ponadto przedstawiono rozważania jego zmniejszenia poprzez zastosowanie urządzeń odbojowych.

Słowa kluczowe: bezpieczeństwo nawigacji, cumowanie statku, odbojnice 


\section{THE SAFETY OF SHIP DURING BERTHING MANOEUVRE PROCESS TO THE QUAY}

\section{Introduction}

The process of navigation consists in the safe and effective passage of the ship to the port of the destination. The berthing manoeuvre of the ship to the quay is the last stage of that process. An ideal manoeuvre would be consisted in a total loss of speed in the moment the ship makes contact with the berth. However, in reality, a dynamic ship's interaction takes place that causes a deformation and stress of the hull and the fender (when applied). The analyses of the manoeuvring tactics of the ship show that first contact of the ship is the most critical moment during berthing. The kinetic energy of the ship in the large part changes in the work of impact in the moment of the first contact of the hull with the berth. It depends on kinetic energy whether mooring will take place without the damages of ship and berth construction or not. It concerns all ships independently from their size, distance done or the kind of the cargo loaded. Therefore it applies to large vessels (bulk carriers, tankers) about the displacement of a few hundred thousands of tons, how and small barges, tugboats, passenger ships, the pleasure crafts (boats, motor boats, yachts) and others as well. Safe berthing is defined as such stop of the vessel near the berth so that losses do not happen. Reduction of the ship's speed to zero in the moment of impact to the quay would be the optimum way to avoid of the breakdown while berthing. It means that the kinetic energy of moving vessel is reduced to zero. Impact is the main reason of losses during berthing where either part or whole energy gives off in the area of contact ship - berth. This energy as the work can cause negative results. It requires special devices with the aim of the improvement of the safety of berthing operations, called fenders or fender systems. Fenders improve the safety of berthing operations by partially absorbing the kinetic energy of the ship. It consists in an elastic deflection (shape elasticity) of the material the ship is made of, and the energy of berthing turns into work of deflection. The fender absorbs a part of ship's kinetic energy. The remaining part of the energy is absorbed by the hull structure and the port structure [4]. Condition of the safety of the maneuver while berthing the ship to the quay can be as follows: 
$E(t) \leq E_{k}^{\text {berth }}$ or $E(t) \leq E_{k}^{\text {ship }}$

where:

$E(t)$ - maximum kinetic energy of the ships impact absorbed by the systen berth - fender - ship,

$E_{k}^{\text {berth }}$ - admissible kinetic energy absorbed by the system berth - fender,

$E_{k}^{\text {ship }}$ - admissible kinetic energy, near which the formed strengths of the reaction of the system berth - fender do not cause the durable deformation of the ships hull yet .

Factors which have the influence on the size of the maximum kinetic energy of the ship's impact against the berth construction are as follows:

- ship maneuverability (kind and the power of the propulsion, thrusters),

- hydrometeorological conditions (wind, current),

- tugs service (the number of tugboats, their power),

- the maneuvering tactics (captain's or pilot's skill)

\section{The kinetic energy of berthing ship}

An important phenomenon during the operation of ship's berthing is energy damping in water as a result of ship's turning. At a certain moment the ship touches the fender and its deformation takes place. Part of the kinetic energy changes then into work of reaction force related to a normal of the berth. For a maximum deformation the speed of ship's contact with the fender drops to zero. That part of energy which as a result has been formed during the deformation of the fender begins to change into a turn motion in relation to the contact point (Fig.1).

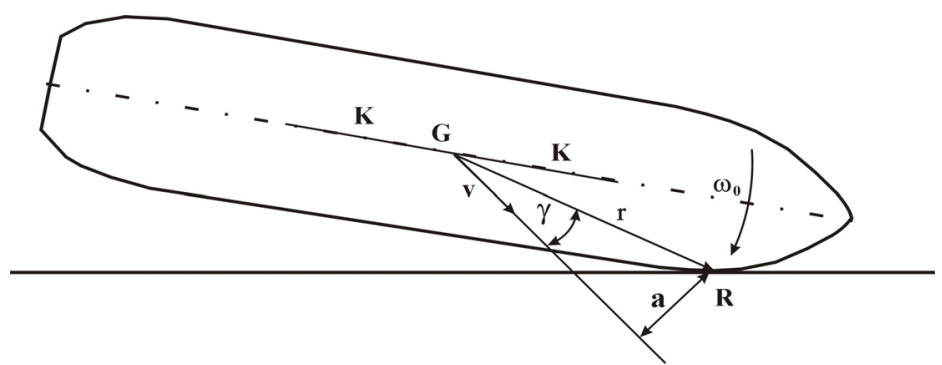

Fig. 1. Ship's impacting against the berth.

It is expressed by gaining the angular velocity in relation to contact point, reaching the top value at the maximum deformation of the fender. Energy 
absorbed by the fender can be estimated from the difference of energy for the ship moving freely, prior to the first contact with the fender and the energy after the impacting (maximum deformation of the fender). The work done on the fender system from the beginning of contact until maximum deflection is reached can be evaluated as difference between the kinetics energy before and after impact. The dependence has been shown by F. Vasco Costa [5]:

$$
E=\frac{m \cdot V^{2}}{2}\left(1-\frac{a^{2}}{K^{2}+r^{2}}\right)-m \cdot V \cdot \omega_{0} \cdot \frac{K^{2}}{K^{2}+r^{2}}+\frac{m \cdot \omega_{0}^{2}}{2} \frac{K^{2} \cdot r^{2}}{K^{2}+r^{2}}[J]
$$

where:

$V$ - ship's linear velocity (translation) $[\mathrm{m} / \mathrm{s}]$

$a$ - the arm of ship's linear movement vector in relation to the point of contact R [m]

$K$ - radius of moment of ship's mass inertia in relation to the point of gravity $\mathrm{G}[\mathrm{m}]$

$r \quad$ - distance between the point of gravity and the point of contact $\mathrm{R}$ [m]

$\omega_{0}$ - ship's velocity of rotation before the impact $\left[\mathrm{s}^{-1}\right]$

This equation gives the amount of kinetic energy of ship to be absorbed by fenders as function of velocity of linear movement of ship and velocity of rotation of the ship impacting mass of the ship

When determining ship's kinetic energy to be absorbed by the fenders the following factors should be taken into account:

- ship's canting when approaching the berthing line

- location of the hull contact point with fender in relation to the ship's centre of gravity

- elasticity properties of the fenders, the shell and the port structure.

- resistance of water between the ship and the port structure

- surface friction in way of contact point between the shell plating and the fender

The above factors cause the kinetic energy of the ship to decline and as a result the fender is forced to absorb part of the entire energy which is understood as the effective energy [3]. The effective energy while berthing the ship to a port structure (knocking into the fenders) will equal:

$$
E=E_{K} \cdot C \quad[J]
$$


Where the $\mathrm{C}$ is total coefficient of energy loss (the product of coefficients of partial loser, which take account of particular vector). In the studies performed so far ship's movement has been shown as a linear speed and vector and speed of turning. Those values can be worked out by means of real observations or by simulation tests. They require a lot of effort. Therefore simplified methods have been applied to determine effective energy of ship's berthing which are based on the component of linear normal berthing speed. The berthing energy can be expressed as:

$E=\frac{m_{w} \cdot V_{n}^{2}}{2} \cdot C \quad[k J]$

where: $V_{n}-$ normal component to berth of ship's speed

The coefficient of eccentricity can be defined as [4]:

$$
C_{E}=\frac{K^{2}+r^{2 \cdot} \cdot \cos ^{2} \gamma}{K^{2}+r^{2}}
$$

where:

$\mathrm{K}$ - radius of moment of ship's mass inertia in relation to the point of gravity $[\mathrm{m}]$,

$r \quad$ - distance between the point of gravity and the point of contact with fender,

$\gamma \quad$ - angle between the normal component of ship's speed and the line crossing ship's gravity point and contact point with the fender.

\section{The effect of ship to the quay}

When analyzing the distance of the contact point from the bow or the distance of that point from the gravity center it can be stated that the change of these values only occurs for a certain range of angles at which the ship approaches the berth (fig.2). The angle $\gamma$ can achieved the value between zero and the maximal value, but not more then $90^{\circ}$. It will depend on ship's angle of approaching the quay. It should be taken into account that exist rigorous relationship between angle of ship's approaching the quay and position of first contact of impact [1]. The distance of this point from bow perpendicular depends on radius of curve of bow or stern hull. The angle of 
ship's approaching the quay can change in interval from $0^{\circ}$ up to $90^{\circ}$. To analyze the distance $r$ between first point of ship's contact with fender and point of ship's centre of gravity, it can find that changing of its value occurs only for some range of angles of ship's approaching the quay $\alpha\left(0, \alpha_{N}\right)$.

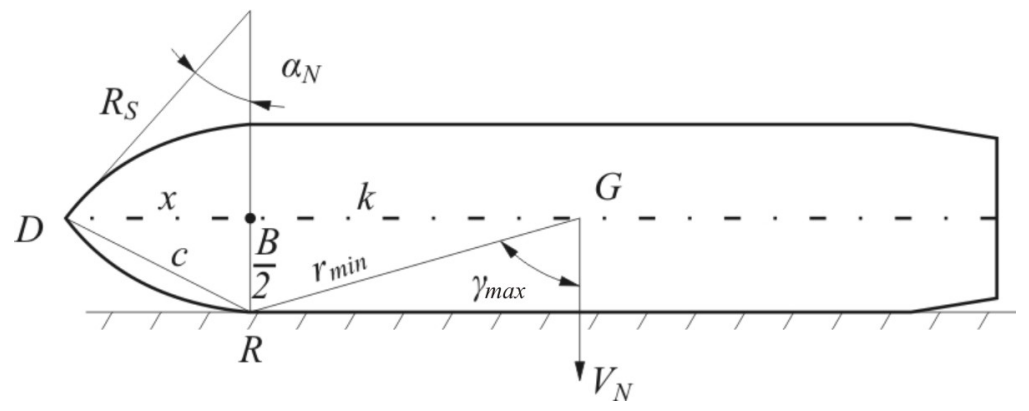

Fig.2. Geometric parameters of ship's berthing

This distance $r$ is called also as radius of ship rotation. Its value evolves from minimal magnitude $r_{\min }$ (for angle of approach $\alpha=0^{\circ}$ ) up to maximal magnitude $r_{\max }$ equals of distance between center of ship's gravity and bow perpendicular - c.a. $\mathrm{L}_{\mathrm{pp}}$ ). For angles of approach in range from $90^{\circ}$ up to same value $\alpha_{N}$, the radius of ship's rotation has maximal and fixed magnitude. For angles less than $\alpha_{N}$, the value of radius starts decreasing up to minimal magnitude for angle of ship's approaching the quay $\alpha=0^{0}$. The value of angle $\alpha_{N}$ will be called as specific value of angle of ship's approaching the quay [2]. It can calculate as:

$\alpha_{N}=\arcsin \left(1-\frac{B}{2 \cdot R_{S}}\right)\left[{ }^{0}\right]$

where: B - breadth of ship [m]

$\mathrm{R}_{\mathrm{S}}$ - radius of ship's hull curves $[\mathrm{m}]$

The minimal value of radius of radius of ship rotation is equal:

$r_{\min }=\sqrt{k^{2}+\left(\frac{B}{2 \cdot R_{s}}\right)}[\mathrm{m}]$

where: k- project of radius of rotation on ships diametrical [m]

$$
k=\overline{D G-x} \quad[\mathrm{~m}]
$$


where:

DG - distance from point of ship's gravity to bow perpendicular [m]

$\mathrm{x}$ - the distance between points of ship's contact with fender and bow perpendicular projected on ships diametrical [m]

where:

$$
x={\sqrt{c^{2}-\left(\frac{B}{2}\right)}}^{2}[\mathrm{~m}]
$$

where:

$$
c=R_{s} \cdot \sin \frac{\alpha_{N}}{2}[\mathrm{~m}]
$$

The maximal value of angle $\gamma_{\max }$ between directions of minimal radius of ship rotation $r_{\min }$ (for angle of angle of ship's approaching the quay $\alpha=0^{0}$ ) and normal component of ships speed to the quay is equal:

$$
\gamma_{\max }=\arcsin \frac{k}{r_{\min }}\left[{ }^{0}\right]
$$

The angle $\gamma$ will be achieved the value in range $0^{0}$ to $\gamma_{\max }$ (but less than $90^{\circ}$ ). The application of described method of eccentricy coefficient determination will permit permits to achieve the higher accuracy than other.

\section{Conclusion}

The manoeuvre of ship's berthing is an important stage of the navigational process. During ships berthing the quay, the effective energy of ship's berthing decided on safety of ship manoeuvring. This energy as a part of kinetic energy of moving ship is absorbed by ship- fender- quay elements. The change of distance between the point of contact and the gravity centre (radius of ship's turning) which in many methods has been treated as a linear change in the function of the angle of approach to the berth, in fact varies in accordance with the radius of the curve of the hull making contact with the berth. The part of ship's kinetic energy is varied into a turn motion in relation to the contact point and mainly is determined by coefficient of 
eccentricy. There are used many methods of determining of eccentricy coefficient value. Practically recommended its value is greater than 0.5 . The analysis of process of ship berthing the quay carried out in paper and elaborated method of eccentricy coefficient calculation permits to achieve the higher accuracy than other. The application of elaborated method of effective energy of ship's berthing the quay permits to optima parameters of fender system.

\section{References}

1. Galor W.: Analiza efektywnej energii dobijania statku do nabrzeża. Zeszyty Naukowe nr 8(80) Akademii Morskiej w Szczecinie, Szczecin 2006.

2. Galor W.: Analiza zmian energii dobijania statku do nabrzeża dla różnych katów podejścia. Proceedings of the XII International Scientific and Technical Conference on Marine Traffic Engineering, Świnoujście 2007.

3. Guidelines for the design of fenders systems. Supplement Bulletin PIANC. Brussels, 2002.

4. Kozioł W., Galor W.: Some Problems of Berthing of ships with NonConventional Propulsions. Materiały konferencyjne TRANS'NAV 2007, "Advances in Marine Navigation and safety of sea transportation". Gdynia 2007.

5. Vasco Costa F., Berthing manoeuvres of large ship. The Dock \& Harbour Authority. March 1968. 


\section{BEZPIECZEŃSTWO STATKU W PROCESIE MANEWRU CUMOWANIA STATKU DO NABRZEŻA}

\section{Wprowadzenie}

Proces nawigacji polega na bezpiecznym i efektywnym przemieszczaniu statku z portu początkowego do portu docelowego. Manewr dobijania (cumowania) statku do nabrzeża jest ostatnim etapem tego procesu. Idealnym manewrem byłby taki, przy którym całkowite wytracenie przez statek prędkości (zmniejszenie do wartości równej zero) nastąpiłoby w momencie kontaktu z nabrzeżem. Jednak w rzeczywistości w większości przypadków następuje dynamiczne oddziaływanie statku na nabrzeże (uderzenie) powodujące odkształcenie i naprężenie kadłuba, nabrzeża i urządzenia odbojowego (jeśli jest stosowane). Analiza taktyki manewrowania statku pokazuje, że najbardziej krytycznym momentem podczas cumowania jest pierwszy kontakt statku z nabrzeżem. Energia kinetyczna statku $\mathrm{w}$ dużej części jest zamieniana na prace uderzenia $\mathrm{w}$ momencie pierwszego kontaktu kadłuba $z$ nabrzeżem. To, czy cumowanie ma miejsce bez uszkodzenia statku i konstrukcji nabrzeża lub $\mathrm{z}$ uszkodzeniem, zależy od energii kinetycznej statku. Dotyczy to wszystkich statków niezależnie od ich wymiarów, danej odległości czy rodzaju przewożonego ładunku. Stąd odnosi się to do dużych statków (masowców, tankowców) o wyporności setek tysięcy ton, jak i małych barek, holowników, statków pasażerskich, jednostek żeglugi rekreacyjnej (łodzi, motorówek, jachtów) i innych małych statków. Bezpieczne dobijanie jest określane jako takie zatrzymanie statku blisko nabrzeża, które nie powoduje uszkodzeń. Redukcja prędkości statku do zera w momencie kontaktu z nabrzeżem jest optymalnym sposobem uniknięcia wypadku podczas dobijania. Oznacz to, że energia kinetyczna statku zostaje zredukowana do zera. Uderzenie jest główną przyczyną uszkodzeń podczas cumowania, gdzie część lub cała energia oddziaływuje w obszarze kontaktu stateknabrzeże. Energia ta jako praca może powodowa negatywne skutki. Wymaga to stosowania specjalnych urządzeń, których celem jest poprawa bezpieczeństwa operacji dobijania, nazywanych odbojnicami lub systemem odbojowym. Odbojnice poprawiają bezpieczeństwo operacji dobijania poprzez częściową absorpcję energii kinetycznej statku. Polega to na elastycznym ugięciu materiału zamianie energii cumowania na pracę ugięcia 
podczas kontaktu statku. Urządzenie odbojowe przejmuje część energii kinetycznej statku. Pozostała część energii jest przejęta przez konstrukcję kadłuba statku i budowli hydrograficznej. Warunkami bezpiecznego dobijania statku są [4]:

$E(t) \leq E_{k}^{\text {berth }}$ or $E(t) \leq E_{k}^{\text {ship }}$

gdzie:

$\mathrm{E}(\mathrm{t}) \quad$ maksymalna energia kinetyczna uderzenia statku absorbowana przez system nabrzeże- odbojnica- statek,

$\mathrm{E}_{\mathrm{k}}^{\text {berth }}$ - dopuszczalna energia kinetyczna absorbowana przez system nabrzeże- odbojnica- statek,

$\mathrm{E}_{\mathrm{k}}^{\text {ship }}$ - dopuszczalna energia kinetyczna dla której siła reakcji w systemie nabrzeże- odbojnica nie spowoduje trwałego odkształcenia kadłuba.

\section{Energia kinetyczna statku}

Jednym z ważniejszych zjawisk podczas dobijania statku do budowli jest thumienie energii $\mathrm{w}$ wodzie $\mathrm{w}$ wyniku obrotu statku. W pewnym momencie statek dotyka urządzenia odbojowego i następuje jego deformacja. Następuje wtedy zamiana części energii kinetycznej statku na pracę siły reakcji normalnej do nabrzeża. Dla maksymalnej deformacji prędkości punktu kontaktu statku z urządzeniem odbojowym maleje do zera. Powstała część energii kinetycznej statku w trakcie deformacji urządzenia odbojowego zaczyna być zamieniana na energię ruchu obrotowego statku względem punktu kontaktu (rys.1).

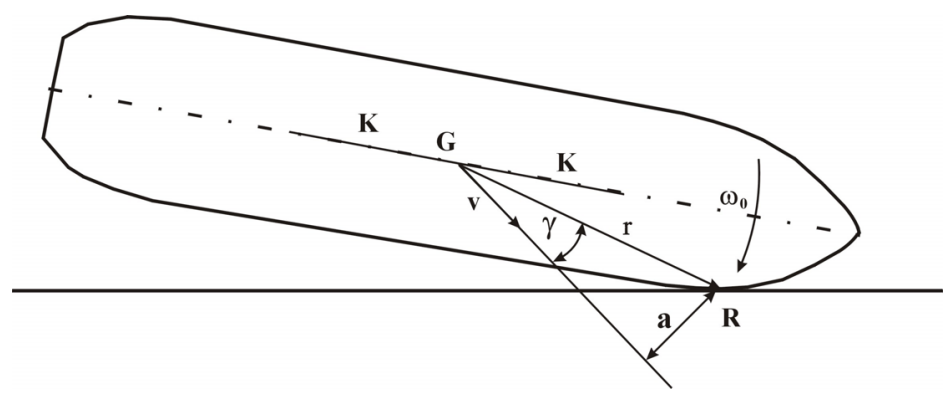

Rys. 1. Uderzenie statku w nabrzeże.

Wyraża się to uzyskaniem prędkości kątowej względem punktu styku, osiagającym maksymalną wartość przy maksymalnej deformacji urządzenia odbojowego. Energia absorbowana przez urządzenie odbojowe jest różnica pomiędzy energią statku poruszającego się swobodnie, przed pierwszym 
kontaktem z urządzeniem i energia po uderzeniu (maksymalnej deformacji urządzenia). Zależność tą przedstawił F. Vasco Costa [5].

$$
E=\frac{m \cdot V^{2}}{2}\left(1-\frac{a^{2}}{K^{2}+r^{2}}\right)-m \cdot V \cdot w_{o} \cdot \frac{K^{2}}{K^{2}+r^{2}}+\frac{m \cdot w_{o}^{2}}{2} \cdot \frac{K^{2} \cdot r^{2}}{K^{2}+r^{2}} \quad[k J]
$$

gdzie:

$V$ - prędkość ruchu liniowego statku $[\mathrm{m} / \mathrm{s}]$

$a$ - ramię działania wektora prędkości liniowej względem punktu kontaktu R [m]

$K$ - promień momentu bezwładności masy statku względem środka ciężkości $\mathrm{G}[\mathrm{m}]$

$r \quad$ - odległość środka ciężkości statku od punktu kontaktu R

$\omega_{0} \quad-\quad$ prędkość obrotowa statku przed uderzeniem $\left[\mathrm{s}^{-1}\right]$

Przy określaniu energii kinetycznej statku przejmowanej przez urządzenie odbojowe należy uwzględnić następujące czynniki:

- kąt podchodzenia statku do linii cumowniczej

- położenie punktu kontaktu kadłuba w stosunku do środka ciężkości statku

- krzywiznę poszycia kadłuba statku na styku z urządzeniem odbojowym

- własności sprężyste urządzenia odbojowego, poszycia kadłuba oraz konstrukcji

- budowli hydrotechnicznej

- opór wody pomiędzy statkiem a budowlą

- tarcie na styku powierzchni poszycia statku i urządzenia odbojowego

Wymienione czynniki powodują zmniejszanie energii kinetycznej statku, i w rezultacie urządzenie odbojowe musi pochłonąć część całkowitej energii i określona jest jako energia efektywna. Energia efektywna podczas dobijania statku do budowli (uderzenia w urządzenia odbojowe) będzie równa:

$$
E=E_{K} \cdot C \quad[J]
$$

gdzie:

$C$ - całkowity współczynnik strat energii będący iloczynem współczynników strat cząstkowych czynników występujących przy dobijaniu.

W dotychczasowych rozważaniach uwzględniano ruch statku opisany wektorem prędkości liniowej i prędkością obrotową. Wartości te można uzyskać w oparciu o obserwacje rzeczywiste lub badania symulacyjne. 
Wymagają one dużego nakładu pracy. Stąd stosuje się uproszczone metody określania efektywnej energii dobijania statku oparte na składowej liniowej prędkości normalnej do nabrzeża. Stąd energia dobijania jest równa:

$$
E=\frac{m_{w} \cdot V_{n}^{2}}{2} \cdot C \quad[k J]
$$

gdzie:

$V_{n} \quad$ - składowa normalna do nabrzeża prędkości liniowej statku

Współczynnik centryczności może by określony jako [4]:

$$
C_{E}=\frac{K^{2}+r^{2 \cdot} \cdot \cos ^{2} \gamma}{K^{2}+r^{2}}
$$

gdzie:

$\mathrm{K}$ - promień momentu bezwładności statku w stosunku środka ciężkości [m],

$\mathrm{r}$ - odległość pomiędzy środkiem ciężkości i punktem kontaktu $\mathrm{z}$ odbojnica $[\mathrm{m}]$,

$\gamma$ - kąt między składową normalną prędkości $\mathrm{V}_{\mathrm{N}}$ a linią łączącą środek ciężkości statku i punkt kontaktu $\mathrm{z}$ urządzeniem odbojowym [ $\left.{ }^{0}\right]$.

\section{Oddziaływanie statku na nabrzeże}

Analizując odległość punktu kontaktu od dziobu lub odległości tego punktu od środka ciężkości można stwierdzić że wartości te zmieniają się dla pewnego przedziału kąta podejścia statku do nabrzeża (rys.2). Kąt $\gamma$ może osiaga wartości $\mathrm{w}$ przedziale od zera do wartości maksymalnej, lecz nie więcej niż $90^{\circ}$. Zależy to od kąta podejścia statku do nabrzeża. Należy zwrócić uwagę, że istnieje ścisła zależność pomiędzy katem podejścia statku do nabrzeża i położeniem punktu pierwszego uderzenia [1]. Odległość tego punktu od pionu dziobowego zależy od promienia krzywizny dziobu rufy. Kąt podejścia statku do nabrzeża może zmienia się w przedziale od $0^{0}$ do $90^{\circ}$. Po analizie odległości $\mathrm{r}$ pomiędzy punktem pierwszego kontaktu statku z odbojnicą i środkiem ciężkości statku można stwierdzić, że zmiana tej wartości występuje tylko dla pewnego przedziału kątów podejścia statku do nabrzeża $\left(0, \alpha_{\mathrm{N}}\right)$. 


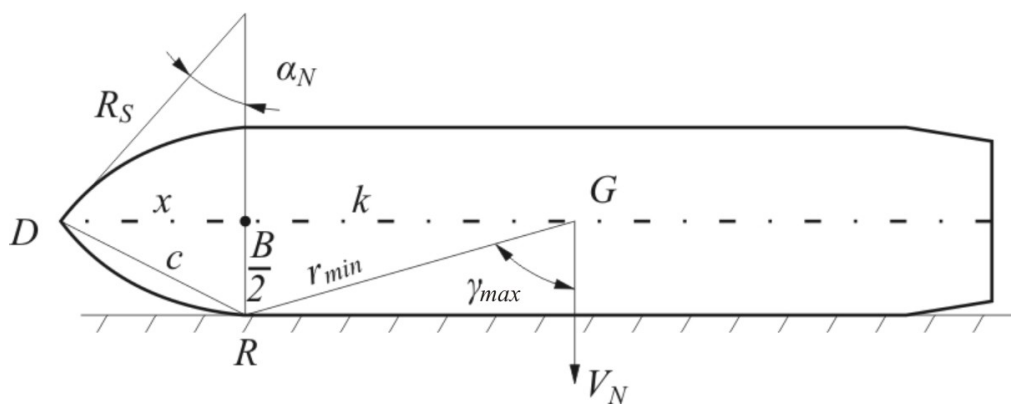

Rys.2. Geometryczne parametry cumowania statku

Odległość r nazywana jest także jako promień obrotu statku. Jej wartość zmienia się od wielkości minimalnej $r_{\text {min }}$ (dla kata podejścia $\alpha=0^{0}$ ), do maksymalnej wielkości $r_{\max }$ równej odległości pomiędzy środkiem ciężkości statku i pionem dziobowym $\mathrm{L}_{\mathrm{pp}}$. Dla kątów podejścia w zakresie od $90^{0}$ do pewnej wartości $\alpha_{\mathrm{N}}$, promień obrotu statku ma maksymalną i stała wielkość. Dla kątów mniejszych niż $\alpha_{N}$, wartość promienia zaczyna się zmniejszać do wielkości minimalnej dla kąta podejścia statku do nabrzeża $\alpha=0^{0}$. Wartość kąta $\alpha_{N}$ może by nazwana jako wartość charakterystyczna kąta podejścia statku do nabrzeża [2]. Może być obliczona jako:

$$
\alpha_{N}=\arcsin \left(1-\frac{B}{2 \cdot R_{S}}\right)\left[{ }^{0}\right]
$$

gdzie:

B - szerokość statku [m]

$\mathrm{R}_{\mathrm{s}} \quad$ - promień krzywizny kadłuba [m]

Wartość minimalna promienia obrotu $r_{\text {min }}$ jest równa:

$$
r_{\min }=\sqrt{k^{2}+\left(\frac{B}{2 \cdot R_{s}}\right)} \quad[\mathrm{m}]
$$

gdzie:

$\mathrm{k} \quad$ - rzut promienia obrotu na diametralną statku

$$
k=\overline{D G-x}
$$

gdzie:

$\overline{D G} \quad$ - odległość środka ciężkości od pionu dziobowego [m]

$\mathrm{x}$ - odległość punktu kontaktu statku z odbojnicą od pionu dziobowego rzutowana na diametralną statku [m] 
$x={\sqrt{c^{2}-\left(\frac{B}{2}\right)^{2}}}^{2}$

gdzie:

$c=R_{s} \cdot \sin \frac{\alpha_{N}}{2}$

Minimalna wartość kąta $\gamma_{\min }$ pomiędzy kierunkiem minimalnego promienia obrotu $r$ min (dla kąta podejścia statku do nabrzeża $\alpha=0^{0}$ ), a składową prędkości statku normalną do nabrzeża wynosi:

$$
\gamma_{\min }=\arcsin \frac{k}{r_{\min }}
$$

\section{Podsumowanie}

Manewr cumowania statku jest ważnym etapem $\mathrm{w}$ procesie nawigacji. Podczas dobijania statku do nabrzeża, efektywna energia cumującego statku decyduje o bezpieczeństwie manewrującego statku. Ta energia jako cześć energii kinetycznej poruszającego się statku jest absorbowana przez elementy statek-odbojnica- nabrzeże. Zmiana odległości pomiędzy punktem kontaktu i środkiem ciężkości (promień obrotu statku), który w wielu metodach jest traktowany jako liniowo zmieniający się $\mathrm{w}$ funkcji kąta podejścia do nabrzeża, w rzeczywistości zmienia się w zależności od promienia krzywizny kadłuba mającego kontakt z nabrzeżem. Część energii kinetycznej statku zamieniana jest na ruch obrotowy względem punktu kontaktu i jest głównie określany przez współczynnik centryczności. Istnieje wiele metod określania wartości tego współczynnika. Praktycznie zalecana jest jego wartość jako większa od 0,5. Analiza procesu cumowania statku do nabrzeża przeprowadzona $\mathrm{w}$ referacie $\mathrm{i}$ opracowana metoda obliczania współczynnika centryczności pozwala na osiagnięcie większej dokładności niż dotychczas. Zastosowanie opracowanej metody określania efektywnej energii dobijającego statku pozwoli na optymalizację parametrów systemów odbojowych.

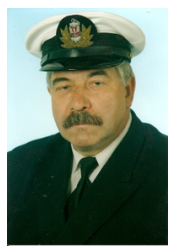

DSc. Eng. Deck Off. GALOR Wiesław, Professor at Institute of Marine Traffic Engineering, Faculty of Navigation, Maritime University of Szczecin, Poland. Specialization: safety of navigation, marine traffic engineering, safety of ship manoeuvring in limited water area, designing of fender systems. Many publications in field. 